\title{
Composition of the Daily Food Ration in Ivory Coast
}

\author{
Drogba Alexis Sahoré ${ }^{1 *}$; Olga Yolande Aké $\mathrm{Ako}^{2}$; Joachim Levry Abouattier ${ }^{3}$ \\ ${ }^{1}$ Food Sciences and Technology Food Sciences and Technology Department, University Nangui Abrogoua Ivory \\ ${ }^{2,3}$ Sciences and Environment Management Department, Nangui Abrogoua University, Abidjan, Ivory Coast \\ * Corresponding author. \\ ABSTRACT: Food products such as yam, cassava, plantain, rice and maize are an important part of food in \\ Ivory Coast. These products are high in carbohydrates and their consumption only covers the energy needs of \\ the population. It is therefore important to provide other foods rich in proteins, lipids and minerals in the daily \\ diet to meet the food needs of this population.
}

KEYWORDS:- Food products, Carbohydrates, Proteins, Minerals, Daily diet, Population

\section{INTRODUCTION}

In Ivory Coast, the farmer traditionally produced for own consumption, and it is the surplus of production that is marketed to meet certain expenses or acquire some material goods [1]. Food products are at the top of all agricultural outputs and, for some of them, have strong annual growth rates [1]. However, food needs are often not met for a variety of reasons: post-harvest losses due to the lack of adequate means of storage, storage and processing, failing collection and distribution channels, population growth, sociocultural convictions etc. [2]. The basis of food in the Ivory Coast is made up of rice, maize, yam, plantain, millet, taro, etc. [3], hence the interest of knowing the nutritive value of these products. The purpose of our study is to analyze some of these products, to know their composition in nutrients (proteins, carbohydrates, lipids) and to compare them. The aim is to demonstrate the need to compensate for the imbalance in the daily food intake of the population that appears to be linked to poor nutritional habits.

\subsection{Vegetable material}

\section{MATERIAL AND METHODS}

The analyzes included samples of maize meal, rice, yam, taro, cassava and plantain (Tableau : 1) purchased from the Abidjan market The samples are then dried, reduced to flour and then stored in glass jars in the refrigerator. These samples are representative of two food groups:

- starchy foods (yams, bananas, cassava),- cereals (rice, maize).

Table 1 : Some food products consumed in Ivory Coast

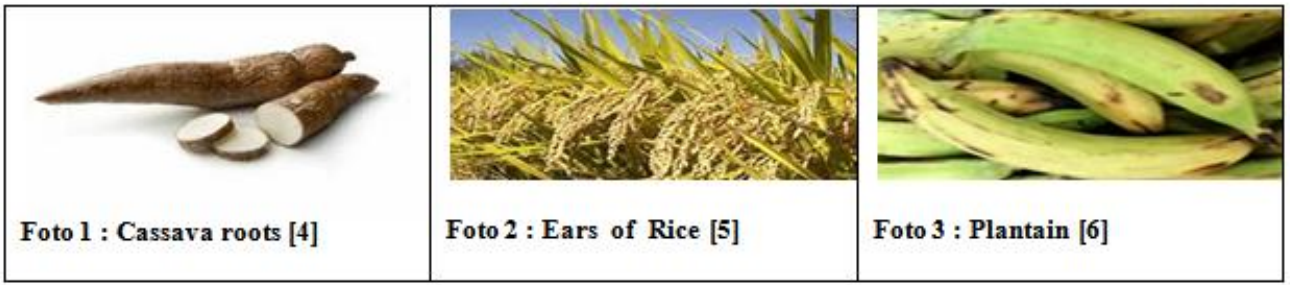

\subsection{Chemical Analysis}

The following analyzes were performed: water content determined by drying $\mathrm{A} 105{ }^{\circ} \mathrm{C}$ to constant weight [10].; protein content determined by the Kjeldahl method of 6.25 as a conversion factor[10].; The lipid content determined by Soxhlet extraction with ether; the ash content determined by incineration at $650{ }^{\circ} \mathrm{C}$ in a muffle furnace [11].; total carbohydrate content determined by difference; the energy value calculated by $(4 \mathrm{x}$ protein content $)+(9.75 \mathrm{x}$ lipid content $)+(4.03 \times$ carb cotent $)$ [12]; the total sugar content is determined by the method of Gabriel Bertrand (1910) [13] after reversal of non-reducing sugars by acid hydrolysis (HCl 12N) for 20 min at $76^{\circ} \mathrm{C}$ in a water bath. 
The results of the analyzes, reported in the Table 2, are given relative to $100 \mathrm{~g}$ of dry matter. Total carbohydrate levels are high for different products. They range from $78.90 \%$ in maize to $82.39 \%$ in plantain. The total sugar content is between $1.59 \%$ in rice and $15.20 \%$ in yam, the value is remarkable in yam $(15.20 \%)$. Protein levels vary. They range from $2.58 \%$ in plantain to $10.50 \%$ in maize. The value is low in plantain $(2.58 \%)$ and relatively high in maize $(10.50 \%)$, yam and rice have intermediate values $(5.8 \%, 6.80 \%)$. The lipid levels are low in all products. They range from $0.31 \%$ in plantain to $2.67 \%$ in corn. The water content in the various flours ranges from $7 \%$ in maize to $11 \%$ in plantain. The dry matter content is between $89 \%$ in plantain and $93 \%$ in maize. The ash content is between $0.93 \%$ in maize and $5.94 \%$ in yam. The energy value is between 342.67 calories in plantain and 381.63 calories in corn

\section{DISCUSSION}

The results of this study show that amylaceous products consumed in Ivory Coast all contain high amounts of carbohydrates. High carbohydrate levels confirm the energy properties of these foods [14] [3].The yam and plantain contain very little fat while levels are slightly significant in rice and maize [15]. The protein contents of these products are very small for the plantain and relatively low in the yam, rice and maize [16].The deficiency in lipids and proteins of some of these foods remains an unfavorable nutritional factor. However, the increasing consumption of these products, which only cover energy needs, suggests that the Ivorian should be provided with other food sources rich in protein for a balanced diet.

\section{CONCLUSION}

The amylaceous products constitute $90 \%$ of the food intake of the Ivorian populations. They do not fully meet the dietary needs, especially protein. To fill this gap, and ensure a good and balanced diet, daily diet should be supplemented by contributions from other protein-rich foods such as eggs, meat, fish and legumes. An analysis of the results shows that corn and rice have a nutritive value slightly above that of plantain and yam.

\section{REFERENCES}

[1] Léon. Y. 1983. Les cultures vivrières et le problème alimentaire de la Côte d'Ivoire Économie rurale Vol. 156 Numéro 1 pp. 41-46

[2] Doumbia S, 1990. Développement du système post-récolte de l'igname et de la banane plantain. Analyse

[3] des contraintes post-récolte et des circuits et des circuits de commercialisation. Abidjan. Univ. Nat. $57 \mathrm{p}$

[4] Aboua F, 1991. Chemical and physical changes in plantains (Musa paradisiacal) during ripening.Trop. Sci. $31-35 \mathrm{p}$

[5] http://www.food-of-africa.com/cassava-recipes/ accessed19/08/2016

[6] https://chasseurmaispascueilleur.wordpress.com/2015/03/06/le-riz/ accessed19/08/2016

[7] http://dico-cuisine.fr/news/sans-titre-4 accessed19/8/2016

[8] http://www.cducentre.com/produit-ignames accessed19/08/2016

[9] http://www.fotosearch.fr/CSP261/k2610135/ accessed19/08/2016

[10] https://fr.search.yahoo.com/search?p=tubercule+de+taro\&fr=yfp-t-FR304 accessed19/08/2016

[11] AOAC, 1980 .Association of official Analytical Chemists, Official Methods of Analysis $11^{\text {th }} \mathrm{ed}$.

[12] Washington, DC

[13] B IPEA, 1976. Bureau Inter professionnel d'Etudes Analytiques

[14] FAO ,1970. Teneur des aliments en acides aminés et données biologiques sur les protéines. RomeItalie, $285 \mathrm{p}$

[15] Bertrand G.T. 1910. Guide pour les manipulations de Chimie. Biologie. Dunod. Paris. $67 \mathrm{p}$

[16] Karou G., 1989.Optimum de maturation de la banane plantain (Orishelé) et paramètres de production

[17] Technologique du foutou banane. Rapport de DEA. Univ. Cocody. Abidjan. 53 p.

[18] Sahoré A.D., Nemlin G. J., Kamenan A, 2007. Changes in nutritional properties of yam (Dioscorea

[19] spp), plantain (Musa spp.) and cassava (Manihot esculenta) during storage; Trop. Sci. 47(2), 81-88

[20] Busson F, 1965. Plantes alimentaires de l'Ouest africain. Ed. Leconte, Marseille 569 p

Table 2 : Composition of somme Foods Crops consumed in Ivory Coast. 


\begin{tabular}{|c|c|c|c|c|c|c|c|}
\hline Products & $\begin{array}{l}\text { Moisture } \\
\% \text { f.p }\end{array}$ & $\begin{array}{l}\text { Proteins } \\
\% \text { d.m }\end{array}$ & $\begin{array}{l}\text { Lipids } \\
\% \text { d.m }\end{array}$ & $\begin{array}{l}\text { Total } \\
\text { Carbohydrates } \\
\% \text { d.m }\end{array}$ & $\begin{array}{l}\text { Sugars } \\
\% \text { d.m }\end{array}$ & $\begin{array}{l}\text { Ashes } \\
\% \text { d.m }\end{array}$ & $\begin{array}{l}\text { Energy } \\
\text { cal/100g } \\
\text { d.m }\end{array}$ \\
\hline Plantain & $\begin{array}{l}11.00 \\
\pm 1.50\end{array}$ & $\begin{array}{c}2.58 \\
\pm 0.13\end{array}$ & $\begin{array}{c}0.31 \\
\pm 0.09\end{array}$ & $\begin{array}{r}82.39 \\
\pm 1.64\end{array}$ & $\begin{array}{c}2.61 \\
\pm 0.11\end{array}$ & $\begin{array}{c}3.72 \\
\pm 0.31\end{array}$ & $\begin{array}{r}342.67 \\
\pm 37.59\end{array}$ \\
\hline Yam & $\begin{array}{c}8.00 \\
\pm 0.80 \\
\end{array}$ & $\begin{array}{c}5.81 \\
\pm 0.02 \\
\end{array}$ & $\begin{array}{c}0.40 \\
\pm 0.07\end{array}$ & $\begin{array}{r}79.85 \\
\pm 2.34 \\
\end{array}$ & $\begin{array}{l}15.20 \\
\pm 0.14\end{array}$ & $\begin{array}{c}5.94 \\
\pm 0.14\end{array}$ & $\begin{array}{l}346.24 \\
\pm 23.22\end{array}$ \\
\hline Rice & $\begin{array}{l}10.00 \\
\pm 0.50 \\
\end{array}$ & $\begin{array}{c}6.80 \\
\pm 0.12 \\
\end{array}$ & $\begin{array}{c}2.59 \\
\pm 0.10\end{array}$ & $\begin{array}{r}79.66 \\
\pm 2.04 \\
\end{array}$ & $\begin{array}{c}1.59 \\
\pm 0.16\end{array}$ & $\begin{array}{c}0.95 \\
\pm 0.21\end{array}$ & $\begin{array}{r}369.15 \\
\pm 20.22\end{array}$ \\
\hline Maize & $\begin{array}{c}7,00 \\
\pm 0,20 \\
\end{array}$ & $\begin{array}{l}10,50 \\
\pm 0,09\end{array}$ & $\begin{array}{c}2,67 \\
\pm 0,05 \\
\end{array}$ & $\begin{array}{r}78,89 \\
\pm 1,94 \\
\end{array}$ & $\begin{array}{c}2,80 \\
\pm 0,11\end{array}$ & $\begin{array}{c}\mathbf{0 , 9 3} \\
\pm \mathbf{0 , 2 0} \\
\end{array}$ & $\begin{array}{l}381,63 \\
\pm 18,22 \\
\end{array}$ \\
\hline Cassava & $\begin{array}{c}7.88 \\
\pm 0.09\end{array}$ & $\begin{array}{r}1 ., 21 \\
\pm 0.09\end{array}$ & $\begin{array}{c}0.85 \\
\pm 0.09 \\
\end{array}$ & $\begin{array}{r}9.550 \\
\pm 0.09 \\
\end{array}$ & $\begin{array}{c}1.05 \\
\pm 0.09 \\
\end{array}$ & $\begin{array}{c}2.44 \\
\pm 0.09\end{array}$ & $\begin{array}{c}395.81 \\
\pm 0.09 \\
\end{array}$ \\
\hline
\end{tabular}

Each value in the table is the average of three determinations $(n=3)$ 